\title{
Large-scale sexual segregation of bowhead whales
}

\author{
M. P. Heide-Jørgensen ${ }^{1, *}$, K. L. Laidre ${ }^{1,2}$, Ø. Wiig $^{3}$, L. Postma ${ }^{4}$, L. Dueck ${ }^{4}$, \\ L. Bachmann ${ }^{3}$ \\ ${ }^{1}$ Greenland Institute of Natural Resources, Box 570, 3900 Nuuk, Greenland \\ ${ }^{2}$ Polar Science Center, Applied Physics Laboratory, University of Washington, Seattle, Washington 98105, USA \\ ${ }^{3}$ Natural History Museum, University of Oslo, PO Box 1172 Blindern, 0318 Oslo, Norway \\ ${ }^{4}$ Fisheries and Oceans Canada, Central and Arctic Region, 501 University Crescent, Winnipeg, Manitoba R3T 2N6, Canada
}

\begin{abstract}
Skin biopsy samples from 806 bowhead whales Balaena mysticetus collected between 1995 and 2010 at 4 locations in Nunavut, Canada, and at 1 locality in West Greenland were used for determination of sex and sexual segregation of bowhead whales in the Baffin Bay stock. There was a significant dominance of females in the Disko Bay samples (78\%), whereas the sex ratio in aggregations in Nunavut was not significantly different from 50:50. Data on the body length of whales suggest that primarily large mature whales without calves occupy Disko Bay, whereas primarily mothercalf pairs are found in Foxe Basin. On a broader scale, Baffin Bay is more widely used by adult males and resting or pregnant females from Disko Bay, while Prince Regent, Gulf of Boothia, Foxe Basin, and northwestern Hudson Bay are also used by nursing females, calves, and sub-adults. The most parsimonious explanation for the large-scale spatial segregation of sexes in bowhead whales is that mature females without calves utilize Disko Bay as a foraging ground during certain parts of their reproductive cycle. Acoustic recordings of singing males indicate that Disko Bay may also be a mating ground, where some males may be following estrous females into the bay.
\end{abstract}

KEY WORDS: Bowhead whale $\cdot$ Balaena mysticetus $\cdot$ Sexual segregation $\cdot$ Skin biopsies $\cdot$ Genetic sex determination

Resale or republication not permitted without written consent of the publisher

\section{INTRODUCTION}

Bowhead whales Balaena mysticetus predictably and seasonally congregate at several coastal locations in the Canadian eastern Arctic and in West Greenland. They are present in Disko Bay, West Greenland (Fig. 1), between February and June, a pattern that has been observed since the 1700s (Eschricht \& Reinhardt 1861). Satellite tracking studies have demonstrated that bowhead whales wintering off the west coast of Greenland spend the summer in the eastern Canadian Arctic and move to the Hudson Strait for the subsequent winter (Heide-Jørgensen et al. 2003, 2006). The abundance of bowhead whales in West Greenland was estimated at 1229 individuals (95\% CI: 495-2939) in 2006 (Heide-Jørgensen et al. 2007). Similarly, bowhead whales are found in large concentrations at specific locations in Foxe Basin, Northern Hudson Bay, in fjords along the east coast of Baffin Island and in the Canadian high Arctic during summer (Davis \& Koski 1980, Finley 1990, Cosens \& Innes 2000, Cosens \& Blouw 2003). In winter, they tend to congregate in Hudson Strait, at the mouth of Cumberland Sound, along West Greenland, and in the North Water (HeideJørgensen et al. 2007).

Based on observations from whalers and various expeditions, it was first noted by Southwell (1898) that bowhead whales in Baffin Bay and Hudson Bay exhibit considerable sex and age-class segregation across their geographic range. According to Southwell (1898), bowhead whales were first encountered by whalers at the northern Labrador coast in winter. Later, in April-May when the whales were found at the entrance to Hudson Strait, old males apparently headed for Disko Bay on the eastern side of Baffin Bay. In May and June, females and immature whales headed north 


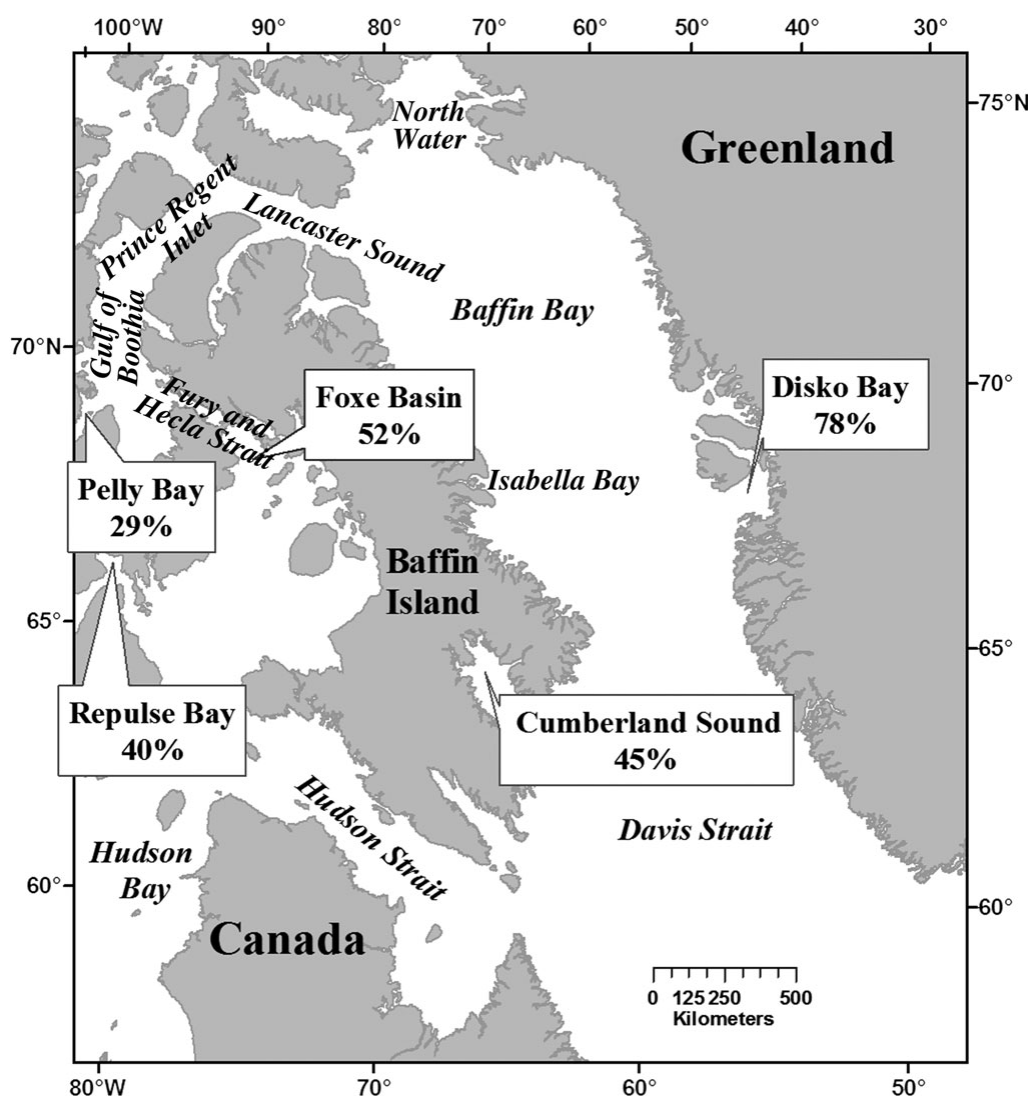

Fig. 1. Locations where bowhead whales were sampled and the percentage of females at each of these locations. Cumberland Sound, Repulse Bay, Foxe Basin and Pelly Bay are included in Nunavut

along the east coast of Baffin Island through leads and cracks. In July, the old males from Disko Bay rejoined the females and immature whales at the entrance to Lancaster Sound, from where they moved west into the Canadian high-Arctic Archipelago, in particular to the Prince Regent Inlet, when ice conditions permitted. The whales abandoned the Canadian high-Arctic Archipelago before fast-ice formed, with the old whales heading south along the east coast of Baffin Island and females with young travelling through the Fury and Hecla Strait into Foxe Basin and Hudson Bay. The various segments of the population wintered in Hudson Strait and along the Labrador coast where parturition was also believed to occur.

The claim by Southwell (1898) that it was primarily old males that headed towards Disko Bay in spring is not in agreement with the reports of females with fetuses in Disko Bay documented by Eschricht \& Reinhardt (1861). However, both Southwell (1898) and Eschricht \& Reinhardt (1861) relied on second-hand observations for obtaining information on sex and size, which was determined only for whales that were killed. The observations by Southwell (1898) were largely ig- nored by the scientific community because of the lack of quantitative evidence of sexual segregation. However, Southwell's (1898) description of the movements of the bowhead whale is in good agreement with modern-day satellite tracking studies of whales in Baffin Bay (Heide-Jørgensen et al. 2003, 2006). The recent increase in bowhead whale abundance in West Greenland and the development of genetic methods has made it feasible to study in more detail the large-scale sexual segregation of bowhead whales in this region. The understanding of the sexual segregation is important for an understanding of the population structure of bowhead whales in eastern Canada and western Greenland.

\section{MATERIALS AND METHODS}

We collected 799 skin biopsies from bowhead whales by means of crossbows with biopsy darts at 5 locations in the eastern Canadian Arctic and in Disko Bay, West Greenland, between 1995 and 2009 (Table 1). An additional 7 samples were collected from the subsistence hunt in Canada and West Greenland for a total sample size of 806. The majority of the samples were collected during field operations in which bowhead whales were instrumented with satellite transmitters. In some communities (Pelly Bay, Repulse Bay) biopsies were collected by local hunters. Since 2007, the sampling in Disko Bay was augmented by supplying a substantial reward (US \$200) to hunters for each biopsy that was collected. The majority of samples in Disko Bay were collected during April and May, and the samples from Nunavut, Canada, were collected between July and September. All samples were stored in salt-saturated $20 \%$ dimethyl sulfoxide (DMSO) and kept frozen until analysis in the laboratories.

Total DNA was extracted from the skin biopsy samples using commercially available DNA extraction kits (DNeasy ${ }^{\circledR}$, Qiagen, E.Z.N.A. or GenElute ${ }^{\mathrm{TM}}$, SigmaAldrich). Molecular sex determination of all whales used a PCR-based approach as described by Berubé \& Palsbøll (1996) or Shaw et al. (2003).

A segment of the mitochondrial control region was amplified and sequenced as described by Rooney et al. (2001). The obtained nucleotide sequences were aligned and edited with the computer program Sequencher 4.1 (GeneCodes), and mitochondrial haplotypes were subsequently assigned to each individual. The obtained information on mitochondrial haplotype and sex allowed for a first prescreening of the 
Table 1. Balaena mysticetus. Sampling period, number of biopsies, and proportion of females in the samples without within-year re-identifications for each of 5 locations in West Greenland and Canada where bowhead whales were sampled. No.: number of whales for which sex was determined; Re-idents.: re-identifications within the same year; Proptn. females: proportion of females (re-identifications removed)

\begin{tabular}{|ccccc|}
\hline $\begin{array}{c}\text { Area } \\
\text { Year }\end{array}$ & Date range & No. & Re-idents. Proptn. \\
& & & & females \\
\hline Disko Bay & & & & \\
2000 & 22-28 April & 7 & 0 & 0.29 \\
2001 & 28 April-8 May & 15 & 3 & 0.58 \\
2002 & 4-13 May & 10 & 0 & 0.60 \\
2003 & 4-18 May & 11 & 1 & 1.00 \\
2004 & 6 May & 1 & 0 & 1.00 \\
2005 & 11 March-3 May & 23 & 0 & 0.74 \\
2006 & 15 April-6 May & 24 & 4 & 1.00 \\
2007 & 10 March-17 May & 138 & 42 & 0.82 \\
2008 & 20 April-3 June & 58 & 14 & 0.77 \\
2009 & 16 February-4 June & 64 & 15 & 0.63 \\
2010 & 7 March-10 May & 90 & 15 & 0.85 \\
Total & & $\mathbf{4 4 1}$ & $\mathbf{9 4}$ & $\mathbf{0 . 7 8}$ \\
Pelly Bay & & & & \\
2000 & September & 1 & 0 & 0.00 \\
2001 & September & 1 & 0 & 1.00 \\
2002 & September & 5 & 0 & 0.20 \\
Total & & $\mathbf{7}$ & $\mathbf{0}$ & $\mathbf{0 . 2 9}$ \\
Foxe Basin & & & & \\
1995 & August & 11 & 0 & 0.73 \\
1996 & 4-6 July & 18 & 0 & 0.39 \\
1997 & August & 2 & 0 & 1.00 \\
2001 & 30 June-6 July & 39 & 1 & 0.45 \\
2002 & 1-15 July & 63 & 2 & 0.48 \\
2003 & August & 30 & 0 & 0.70 \\
2007 & July & 34 & 2 & 0.47 \\
Total & & $\mathbf{1 9 7}$ & $\mathbf{5}$ & $\mathbf{0 . 5 2}$ \\
Repulse Bay & & & & \\
1995 & September & 1 & 0 & 0.00 \\
1997 & August to September & 6 & 3 & 0.67 \\
1998 & September & 4 & 0 & 0.25 \\
2000 & September & 4 & 0 & 0.75 \\
2001 & September & 3 & 0 & 0.00 \\
Total & & $\mathbf{1 8}$ & $\mathbf{3}$ & $\mathbf{0 . 4 0}$ \\
Cumberland Sound & & & \\
1997 & June to August & 21 & 2 & 0.32 \\
2002 & June to August & 7 & 1 & 0.67 \\
2004 & June to August & 8 & 0 & 0.63 \\
2005 & June to August & 17 & 1 & 0.44 \\
2006 & June to August & 29 & 0 & 0.45 \\
Total & & $\mathbf{8 2}$ & $\mathbf{4}$ & $\mathbf{0 . 4 5}$ \\
\hline
\end{tabular}

sampled individuals with respect to potential recaptures. Same-sex individuals with the same haplotypes were furthermore compared with first 4, and then up to 8, highly variable microsatellite loci (Huebinger et al. 2008). Further, alleles at all loci were compared for all samples to identify identical genotypes. Within-year replicate samples were removed from further analysis.

\section{RESULTS AND DISCUSSION}

Sex was determined for 745 samples from a total of 806 biopsies collected from bowhead whales in Canada and Greenland from 1995 through 2010 (Table 1). A total of 106 re-identifications within the same year collected from Foxe Basin, Disko Bay, and Cumberland Sound were removed from further analysis. Both the number of samples and the proportion of replicates increased dramatically after 2006 when the sampling in Disko Bay was stimulated by a reward given to the hunters.

Females made up $78 \%$ of the overall proportion of whales in Disko Bay when all years were combined and after removing within-year re-identifications. This was slightly lower than the estimate of $82 \%$ females for 2007 alone, the year with the largest sample size ( $\mathrm{n}=$ 96). The most extreme case was in 2006, when no males were detected out of 20 samples.

Northern Foxe Basin provided the largest sample size from Nunavut $(n=192)$, with a sex ratio for all $7 \mathrm{yr}$ of $52 \%$ females. Smaller samples from Repulse Bay and Cumberland Sound had sex ratios of 40 and $45 \%$ females, respectively, and an even smaller sample from Pelly Bay $(n=7)$ had a female proportion of $29 \%$ (Fig. 1).

The observed proportion of females in Disko Bay was significantly different from the expectation of equal proportions of males and females (G-test, p < 0.001, $G=117.4$ ), but no significant differences from a 1:1 sex ratio were detected for Foxe Basin, Cumberland Sound, Pelly Bay, or Repulse Bay ( $p>0.27)$. Nothing suggests that there is a selective sex-biased effort in the sampling of the various areas, and the difference must be considered real.

Despite the large number of whales that were taken along West Greenland in the 18th and 19th centuries, only 2 observations of newborns were reported (Eschricht \& Reinhardt 1861), indicating that this was not a major calving ground. For the 20th century, there was only 1 reported observation of a mother and calf in Disko Bay from ca. 1920 (Knudsen 1983). During extensive aerial surveys conducted between 1981 and 2006 in West Greenland, calves or immature whales were only detected once (n > 50), on 25 April 2006, about $100 \mathrm{~km}$ west of the Greenland coast at $68^{\circ} 08^{\prime} \mathrm{N}$, $56^{\circ}$ 02' W (Heide-Jørgensen et al. 2007, D. Boertmann pers. comm.). Similarly, observations made during field operations from 2000 to 2010 confirm that it is essentially adult whales ( $>14 \mathrm{~m}$, with some whales $>12 \mathrm{~m}$ ) which are found in Disko Bay in spring (HeideJørgensen et al. 2003, 2006). A recent revival of Inuit subsistence hunting for bowhead whales in West Greenland in 2009-2010 resulted in catches of 5 females and 1 male bowhead whale, all >14 m, confirm- 
ing that the whales in Disko Bay are primarily large mature females (Heide-Jørgensen et al. 2010).

Few calves have been reported from other areas of Baffin Bay: Davis \& Koski (1980) reported less than $3 \%$ ( $\mathrm{n}=46$ observations of whales) calves during fall aerial surveys of Lancaster Sound. In Isabella Bay (Fig. 1), Finley (1990) measured 83 bowhead whales with a mean length of $14.4 \mathrm{~m}$ on aerial photographs; only 1 cow-calf $(6 \mathrm{~m})$ pair and 1 sub-adult whale $(<10 \mathrm{~m})$ were detected. Land-based observations $(n>100)$ in Isabella Bay during 1984 to 1988 confirm that mother-calf pairs and sub-adults were rarely seen along the east coast of Baffin Island in August. An aerial survey in September 2009 in Isabella Bay similarly revealed no sightings of immature whales (Hansen et al. 2010). Results from these studies strongly suggest that the bowhead whales occupying Baffin Bay and Davis Strait during summer and fall are mainly adults.

Disko Bay has a disproportionate number of adult female bowhead whales. This, along with sex-ratio proportions from other sampled areas, suggests that the whales observed in Disko Bay do not represent the whole stock. These whales are more likely a fraction of a larger population that temporarily segregates throughout the eastern Canadian high Arctic. With the increased abundance of bowhead whales in West Greenland (Heide-Jørgensen et al. 2007), it is also likely that a substantial number of whales must be migrants from other areas.

The main calf-producing fraction of the population can be found in the complex archipelago of the Canadian high Arctic. Historical whaling records clearly indicate that cows, calves, and sub-adult whales were taken in northwestern Hudson Bay from June through September (Reeves \& Cosens 2003). Recent aerial photogrammetric and visual studies have shown that bowhead whales in Foxe Basin mainly consist of young-ofthe-year calves and sub-adults, and the majority of adult individuals were believed to be cows with young-of-the-year calves (Cosens \& Innes 2000, Cosens \& Blouw 2003). Apparently, there are few adult males and resting females in Foxe Basin and northwestern Hudson Bay, and no large assemblages of only adult whales have been reported within Hudson Bay and Foxe Basin. The biopsy samples from Foxe Basin have an even sex ratio, which is consistent with the assumption of a mixing ground for immature whales of both sexes and females with calves. The samples from Repulse Bay suggest that this area is frequented by more males than females. The sample from Pelly Bay is too small to support the suggestion of the Gulf of Boothia being a nursing ground (Markham 1874, Southwell 1898, Finley 2001). There is a slight preponderance of males $(57 \%)$ in the Cumberland Sound samples that could account for the missing males in
Disko Bay and that confirm Southwell's (1898) description of primarily males along east Baffin Island.

Bowhead whales exhibit large-scale sexual segregation that is spatially defined. Traditionally, sexual segregation in other vertebrates has been explained by predation risk, forage selection, or activity budgets (Ruckstuhl 2007). Predation risk does not explain occurrence in Disko Bay, as there are only few reports of killer whales in this area in winter and spring when bowhead whales are present in the bay, and no other predators (aside from humans) threaten bowhead calves in West Greenland. To a large extent, different age and sex groups feed on the same types of prey (calanoid copepods), and aside from migration patterns, no obvious behavioral differences can convincingly explain why mature females choose to visit Disko Bay in spring and why mothers and calves aggregate in Foxe Basin. From a habitat perspective, Disko Bay differs from the other bowhead habitats in that is has a much longer ice-free season (8 mo versus 2 mo in Foxe Basin), deeper water (400 versus $<90 \mathrm{~m}$ in Foxe Basin), and a more diverse marine production influenced by the warm West Greenland current of Atlantic origin. At the same time, the shallow and sheltered yet relatively unproductive waters of Foxe Basin may offer a refuge for young bowhead calves. The most parsimonious explanation for the seasonal occurrence of mature bowhead whales, most of which are females, in Disko Bay is the foraging opportunity offered by the highly productive waters of the bay. Differences in seasonal feeding intensity of bowhead whales have also been observed in the Pacific population (Lee et al. 2005). The whales that visit Disko Bay in spring benefit from substantial springtime marine production and a large abundance of copepods (Laidre et al. 2007), and postlactating, pregnant, or resting females are able to regain fat depots that are otherwise difficult to maintain in the less productive Central Canadian Arctic Archipelago during short stays in the bay.

There are also indications from acoustic studies that Disko Bay, perhaps prior to the beginning of feeding, is a mating ground. Mating is believed to occur in March and April (Reese et al. 2001). Intensive singing activity of bowhead whales, with up to 3 unique songs, was recorded in April 2007 (Stafford et al. 2008, Tervo et al. 2009). Singing is an activity that is usually attributed to male display in baleen whales, and given that most singing activity was recorded during spring, it is plausible that mating between the relatively few males and the large fraction of females occurs in Disko Bay.

Harvest sampling from whales killed in Disko Bay in 2009-2010 ( $\mathrm{n}=5$ females and 1 male) indicated that one of the females was pregnant with a near-term fetus, 2 were recently pregnant, and 1 was resting (Heide-Jørgensen et al. 2010). Not all females will be 
available for mating and thus a 1:1 sex ratio is not expected. It is likely that the occurrence in Disko Bay is part of a multi-year reproductive cycle for the females, where years with calving and nursing are spent in the Central Canadian Arctic Archipelago, and pregnant or post-lactating females feed intensively in the bay. That may explain the relatively low level of recaptures between years observed in Disko Bay (Wiig et al. 2010).

In 1977, a 2-stock hypothesis for bowhead whales occupying eastern Canadian and western Greenlandic waters was adopted as the working model of the International Whaling Commission (IWC; Allen 1978). The stocks were identified as the Baffin Bay-Davis Strait (BB-DS) or Baffin Bay stock and the Hudson Bay-Foxe Basin (HB-FB) or Hudson Bay stock and have been treated as separate populations since (see Mitchell \& Reeves 1981, IWC 1999, Cosens \& Innes 2000, Finley 1990, 2001).

Given that bowhead whales from these stocks are subject to a limited hunt in the Canadian Arctic and that a quota was recently assigned by IWC to the West Greenland wintering aggregation of bowhead whales (www.iwcoffice.org/conservation/catches.htm\#aborig), it is timely to re-assess the population structure of these whales in light of new information that has been collected. Heide-Jørgensen et al. (2006) suggested that the bowhead whales summering in eastern Canada and wintering in West Greenland might consist of a single population. Based on satellite tracking studies of bowhead whales tagged in West Greenland, they argued that bowhead whales are capable of travelling long distances in relatively short periods of time and suggested that there was no reason why whales should be restricted to relative small portions of the total potential range in eastern Canada and Greenland waters. They also noted that there was little geographical separation between individuals belonging to the 2 putative stocks.

Given the available data, the most reasonable explanation for the sex-segregation discussed in the present study is that bowhead whales summering in the eastern Canadian Arctic and wintering off the west coast of Greenland belong to just one population, with mainly adult males and resting and pregnant females occupying Baffin Bay, and nursing females, calves, and subadults in the Prince Regent, Gulf of Boothia, Foxe Basin, and northwestern Hudson Bay.

Acknowledgements. This study was funded by the Greenland Institute of Natural Resources, the Commission for Scientific Research in Greenland, the Danish Cooperation for the Environment in the Arctic under the Danish Ministry of Environment, the National Ocean Partnership Program (Office of Naval Research and US National Science Foundation), and the Department of Fisheries and Oceans. M. Lindsay, C. Lindqvist, B.E. Michalsen and D. Tenkula kindly assisted with the laboratory analysis, and B. Dunn and J. Higdon assisted in the field with the collection of samples. We also thank the hunters in Greenland and Canada for collecting the majority of the samples and the University of Copenhagen for providing access to its Arctic Station in Disko Bay.

\section{LITERATURE CITED}

Allen KR (1978) Report of the Scientific Committee. Rep Int Whal Comm 28:38-92

> Berubé M, Palsbøll P (1996) Identification of sex in cetaceans by multiplying with three $2 \mathrm{FX}$ and $2 \mathrm{FY}$ specific markers. Mol Ecol 5:283-287

Cosens SE, Blouw A (2003) Size- and age-class segregation of bowhead whales summering in northern Foxe Basin: a photogrammetric analysis. Mar Mamm Sci 19: 284-296

Cosens SE, Innes S (2000) Distribution and numbers of bowhead whales (Balaena mysticetus) in northwestern Hudson Bay in August 1995. Arctic 53:36-41

Davis RA, Koski WR (1980) Recent observations of the bowhead whale in the Eastern Canadian High Arctic. Rep Int Whal Comm 30:439-444

Eschricht DF, Reinhardt J (1861) Om nordhvalen (Balaena mysticetus L.) navnlig med hensyn til dens udbredning $\mathrm{i}$ fortiden og nutiden og til dens ydre og indre saerkjender. K Dan Vidensk Selsk Biol Skr Ser 5, Naturvidensk Math Afd 5:433-590

Finley KJ (1990) Isabella Bay, Baffin Island: an important historical and present-day concentration area for the endangered bowhead whale (Balaena mysticetus) of the eastern Canadian Arctic. Arctic 43:137-152

Finley KJ (2001) Natural history and conservation of the Greenland whale, or bowhead, in the Northwest Atlantic. Arctic 54:55-76

Hansen RG, Heide-Jørgensen MP, Laidre KL (2010) Recent abundance of bowhead whales in Isabella Bay, Canada. Rep Int Whal Comm SC62/BRG28

Heide-Jørgensen MP, Laidre KL, Wiig $\varnothing$, Jensen MV, Dueck L, Maiers L, Schmidt HC, Hobbs RC (2003) From Greenland to Canada in two weeks: movements of bowhead whales, Balaeana mysticetus, in Baffin Bay. Arctic 56: $21-31$

Heide-Jørgensen MP, Laidre KL, Jensen MV, Dueck L, Postma LD (2006) Dissolving stock discreteness with satellite tracking: bowhead whales in Baffin Bay. Mar Mamm Sci 22:34-45

Heide-Jørgensen MP, Laidre KL, Borchers D, Samara FIP (2007) Increasing abundance of bowhead whales in West Greenland. Biol Lett 3:577-580

Heide-Jørgensen MP, Garde E, Nielsen NH, Andersen ON, Honoré Hansen S (2010) Biological data from the hunt of bowhead whales in West Greenland 2009 and 2010. Rep Int Whal Comm SC62/BRG27

Huebinger RM, Patton JC, George JC, Suydam R, Louis EE, Bickham JW (2008) Characterization of twenty-five microsatellite loci in bowhead whales (Balaena mysticetus). Mol Ecol Res 8:612-615

IWC (International Whaling Commission) (1999) Report of the Scientific Committee. J Cetacean Res Manag 1(Suppl): $1-284$

Knudsen E (1983) Grønlandshvalen vrikkede med motorbåden. Grønl Selsk Skr 26:54-64

Laidre KL, Heide-Jørgensen MP, Nielsen TG (2007) The role 
of the bowhead whale as a predator in West Greenland. Mar Ecol Prog Ser 346:285-297

Lee SH, Schell DM, McDonald TL, Richardson WJ (2005) Regional and seasonal feeding by bowhead whales Balaena mysticetus as indicated by stable isotope ratios. Mar Ecol Prog Ser 285:271-287

Markham AH (1874) A whaling cruise to Baffin's Bay and the Gulf of Boothia in the whaler Arctic commanded by Captain Adams. Low and Searle, London

Mitchell E, Reeves RR (1981) Catch history and cumulative catch estimates of initial population size of cetaceans in the eastern Canadian Arctic. Rep Int Whal Comm 31: 645-682

Reese CS, Calvin JA, George JC, Tarpley RJ (2001) Estimation of fetal growth and gestation in bowhead whales. J Am Stat Assoc 96:915-923

Reeves RR, Cosens SE (2003) Historical population characteristics of bowhead whales (Balaena mysticetus) in Hudson Bay. Arctic 56:283-292

Rooney AP, Honeycutt RL, Derr JN (2001) Historical population size change of bowhead whales inferred from

Editorial responsibility: Ana Cañadas,

Madrid, Spain
DNA sequence polymorphism data. Evolution 55: 1678-1685

Ruckstuhl KE (2007) Sexual segregation in vertebrates: proximate and ultimate causes. Integr Comp Biol 47:245-257

Shaw CN, Wilson PJ, White BN (2003) A reliable molecular method of gender determination for mammals. J Mammal 84:123-128

Southwell T (1898) The migration of the right whale (Balaena mysticetus). Nat Sci 12:397-414

Stafford KM, Moore SE, Laidre KL, Heide-Jørgensen MP (2008) Bowhead whale springtime song off West Greenland. J Acoust Soc Am 124:3315-3323

Tervo OM, Parks SE, Miller LA (2009) Seasonal changes in the vocal behavior of bowhead whales (Balaena mysticetus) in Disko Bay, Western Greenland. J Acoust Soc Am 126:1570-1580

Wiig Ø, Bachmann L, Heide-Jørgensen MP, Laidre KL, Postma LD, Dueck L, Palsbøll PJ (2010) Within and between stock re-identifications of bowhead whales in eastern Canada and West Greenland. Rep Int Whal Comm SC62/BRG65

Submitted: May 17, 2010; Accepted: September 16, 2010 Proofs received from author(s): December 22, 2010 